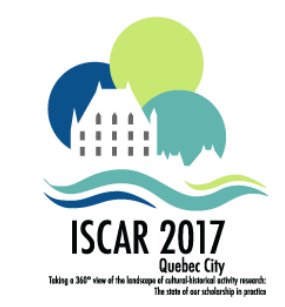

\title{
Pedagogical, Psychological and Psychotherapeutic Help in Overcoming Learning Difficulties to Facilitate Development
}

\author{
Different Methods of Help from the Cultural-Psychological Viewpoint
}

Viktor K. Zaretskii

ZAR-VICTOR@YANDEX.RU

Moscow State University of Psychology and Education

Moscow, Russia

\author{
Alla B. Kholmogorova \\ KHOLMOGOROVA-2007@YANDEX.RU \\ Moscow State University of Psychology and Education \\ Moscow Research Institute of Psychiatry - Branch of The Serbsky Federal Medical Research \\ Center for Psychiatry and Narcology
}

\begin{abstract}
The paper discusses theoretical basics for organising the work and interaction of different specialists helping children with learning difficulties (teachers, counsellors, therapists). The multivector model of the zone of proximal development based on cultural-historical psychology and developed in the theoretical framework of Reflection-Activity approach is proposed as such basic value. We connect different types of help to various developmental vectors and regard them as technologies to enhancing the client's development. We reveal the contents of such notions as cooperation, zone of proximal development, agency, reflection, and problem's epicentre. We present different ways of operationalizing these notions applied to aiding children with learning difficulties. The notion of dual resource we propose is important for developing new techniques of working in the zone of proximal development; it is this basis certain technologies of organising the client's reflection are relying on. We give examples of counselling children in such way and present a comparative analysis of the counsellor's work with action schemas and cognitive-behavioural therapist's work with problematic emotional states and behaviours in children with learning difficulties. The theoretic system we disclose helps to comprehend the famous quote from Lev Vygotsky: "one step in learning may signify a hundred steps in development".

Keywords : Cultural-historical psychology; Development; Learning; Help in overcoming learning difficulties; Pedagogics; Psychological counselling; Cognitive-behavioural therapy; Reflective-activity approach; Multivector model of the zone of proximal development; Position of agency; Reflection; Dual resource; Problem's epicenter.
\end{abstract}


The number of children with learning difficulties is steadily increasing. It raises the issue of knowledge a specialist helping them should possess. They are usually referred to tutors, pedagogic psychologists, neuropsychologists and psychotherapists - the latter in case a serious threat to mental health is diagnosed. What kind of help can a child get from each of these specialists? A tutor can adapt the process of education to the child's capabilities and help amend his/her knowledge gaps. A neuropsychologist can diagnose the underdevelopment of brain structures and mental functions and propose a correction program. A pedagogic psychologist can also diagnose cognitive and personal characteristics of a child and recommend an optimal way of interpersonal communication to his/her parents and teachers. The most difficult cases arise, for example, in teaching orphaned children with disabilities and severe somatic illnesses, who need prolonged hospital treatment, which isolates them from the system of education, family and society in general. In these cases, different vectors of development get tied in an intricate knot, which can't be loosened by a single specialist.

In cases like these "what a single person cannot do, two can", according to Feuerbach - that is, they require a team of specialists. Questions arise: How to define the top-priority treatment targets? Where can specialists find the problem's epicentre to achieve a breakthrough in development? The principal issue is the following: how can different specialists agree upon the principles of interaction?

Evidently, the answer to these questions lies in the views on the process of development, which should be shared by all the members of the team; otherwise, their work can become chaotic, uncoordinated and ineffective, if not harmful. These views should rely on certain values, which give direction to the work process. For example, numerous pedagogical approaches differ in defining the child's agency in the learning activity, which is reflected in the opposition of "authoritarian pedagogy" versus "pedagogy of cooperation" (Dzhurinskii, 2008). In authoritarian pedagogy, a child is an object influenced by an adult. This idea is most strikingly expressed by the concept of tabula rasa, which an adult can "write" everything on. In pedagogy of cooperation, a child is an agent of the learning activity equal to an adult.

Such underlying values that can unite different specialists in child development can be found in cultural-historical psychology, an approach developed by Vygotsky (1956, 1982, 1984).

The model of mental development in cultural-historical psychology includes several basic notions:

1. culture is a source of development; it can be considered a system of "tools" for organising mental processes which were accumulated during the evolution of society;

2. learning is a driving force of development; mental tools are appropriated in the process of learning;

3. internalization is a process of turning the outer tools (means) into the inner ones; it is a crucial mechanism of development; 
4. cooperation of a child and an adult, which takes place in the zone of proximal development of the child, becomes the most significant condition of development.

In the paper, we consider new workings in Russian psychology based on this model, which aim at facilitating the development of children with learning difficulties in pedagogical, psychological and psychotherapeutic counselling. It was this task (namely, promoting development through learning) that primarily interested L. S. Vygotsky, as the bulk of his works is devoted to developmental disorders and their treatment (V. K. Zaretskii, 2015, 2016).

From the viewpoint of cultural-historical psychology learning difficulties block the development on the whole if untreated. Learning and development are closely connected, and different methods of psychological and pedagogical help can be regarded as development facilitators.

Psychological-pedagogical support may be reduced to teaching. Psychotherapeutic aid may be considered a treatment. We regard both as different approaches (or techniques) to creating the necessary conditions for the development of the person who receives help. Thus, a psychotherapist and a pedagogic psychologist (a teacher) deal with the same process, but from different angles. Teachers deal with development in the context of acquiring new knowledge in the academic setting; psychotherapists help their clients overcome the causes of mental disorders, and acquire the skills of psychological selfregulation. This division is the result of the inevitable specialisation and differentiation of knowledge in each of the contexts.

Pedagogical activity (psychological-pedagogical help in overcoming learning difficulties) includes not only knowledge transmission, but also re-education (overcoming inadequate spontaneous behaviours) and changing attitudes and mindsets, as every activity including learning requires personal input. The latter indicates that the personality dimension is present in every activity, including pedagogical. If learning difficulties are connected to the child's personal problems, the psychotherapeutic approach may be needed to overcome them. For example, the child's conviction that he/she is not going to achieve anything renders any pedagogical help useless, because he/she cannot assimilate it. Only if this mindset is overcome, the efforts - made sense of, the child - involved into activity as a subject, can the pedagogical activity be effective. In such cases, the prerequisite of successful pedagogical help is overcoming the mindset that hinders the mastery of new material, which makes this process close to psychotherapy. Thus we can use the metaphor of figure-ground from Gestalt psychology: pedagogical help is a shape, and psychotherapeutic aspect is a background. In different situations figure and ground can change places. In the process of counselling, the child's problem's epicentre can change its position relative to the field of knowledge, thus, to overcome difficulties and create favourable conditions for future development a pedagogical psychologist needs to modify the techniques.

As we already mentioned, overcoming learning difficulties can be achieved through working on personal problems (chronic failure and resulting learned helplessness, passive or negative attitude towards studies, lack of meaning in connection to studies) or inadequate 
action schemas in certain types of learning activity. This variety calls for setting different epicentres (targets) and moving along multiple vectors of development.

In connection to this, practical work demands developing counselling methods for treating learning difficulties based on the comprehensive conception of development and its different vectors. It is satisfied by Reflection and Activity approach (RAA), which has been developing for the last 20 years to assist children with learning difficulties relying on the concept of development from cultural-historical psychology. RAA as a psychological counselling approach relies on the multivector model of development (V. K. Zaretskii, 2013, 2016) and strives to integrate knowledge from psychotherapy, pedagogics and developmental psychology. It aims to equip teachers with such psychological knowledge about development that can help them to see not only the local difficulty their student experiences in their subject but the comprehensive picture of development. In this new context, the local learning difficulty can become a source of further development, or hinder psychological growing resulting in the loss of confidence and trust in others. On the other hand, despite having basic knowledge of developmental processes psychologists usually lack the necessary knowledge of teaching school subjects, which makes their work onesided. RAA psychologists usually improve their counselling skills and learn the subject the child experiences difficulties in altogether, which greatly improves their potential to help the child. We suppose that this is the teacher Blonskii (1979) and Vygotsky (1956) were dreaming of - the one who possesses knowledge both on the subject and the process of development.

\section{Basic concepts used in learning difficulties counselling: cooperation, zone of proximal development, dual resource, and agency}

In the previous decade integration of RAA, cognitive-behavioural and existential approaches in psychotherapy became a subject of studies (Kholmogorova \& Zaretskii, 2010, 2011; Nikolaevskaya, 2017). Pedagogical as well as psychological work starts with the most crucial stage - establishing a bond. Psychotherapist Frantz Caspar noted: "A psychotherapeutic bond is a factor most convincingly related to the outcome of psychotherapy. There is little use though in recommending therapists to establish a good bond without defining how exactly to reach this goal" (Caspar, 2010, p. 47). The same can be attributed to pedagogical activity. Teacher and student grow together, a principle stated by Confucius, which was put into practice in 20th century Russia in the pedagogics of cooperation, its primary role in child development pointed out by Vygotsky (1984). Cooperation can be considered a prerequisite for development and a basic value, which should be shared by each member of the team.

To give an example of cooperation, we turn to the works of Arnhild Lauveng, a Norse writer and clinical psychologist, who had a severe mental illness as an adolescent and described her way to recovery in autobiographic books. Summarizing her experience of a

mental disorder and recounting different mental health specialists she met, Lauveng writes the following: 


\begin{abstract}
"Recalling what worked for me and what didn't, I guess, the main reason why anyone had any success with me lay in their cooperation with me. They used and developed my resources and helped me compensate my weaknesses, and made sure I were on their side not because of some legal action, but just because it was my life, my personality, my illness, and in the end only I could do anything with it. I couldn't get better on my own, without anyone's help, but no outside helpers could aid me without my activity. Evidently, this is what should be defined as cooperation" (Lauveng, 2009, p. 207).
\end{abstract}

However, how is the bond based on the established cooperation? What should be done by an adult to take a position of a cooperator, not a mentor, and what should be done by a child with the help of the adult to change form a student (or patient) into a cooperator, that is, a subject of an activity shared with the adult? Klaus Grawe, famous for studying factors contributing to the effectiveness of psychotherapy, formulated a rule, which can help reach this goal: the problem should not be actualized before the resources to overcome it are activated (Grawe, 2006). Nevertheless, a therapist abiding by this rule may wonder: How does one create the favourable conditions to activate the resources of the patient? What should be done if they are sufficient, and what should be done if they are not?

Studying the relationship between learning and development, Vygotsky formulated another basic value that should be shared by the specialists no matter what course of development they are working with: that is, operating in the zone of proximal development (ZPD). According to Vygotsky, only in this case can the adult's help be efficient and useful.

As we showed in the previous works (Kholmogorova \& Zaretskii, 2010, 2011), Grawe's principle of resource activation and Vygotsky's principle of ZPD are closely related, the latter being a heuristic for specifying the conditions in which the former can be realized. To reveal this heuristic, we proposed a concept of dual resource, which emerges in the zone of proximal development. The notion of dual resource helps to understand how to achieve resource activation and build-up during work in $\mathrm{ZPD}$, and how to overcome difficulties.

Originally Vygotsky distinguishes between the zone of proximal development and the zone of actual development (Vygotsky, 1956, 1984). While the zone of proximal development signifies a domain of actions and behaviours that a child can only perform with the help of an adult, zone of actual development is, according to Vygotsky, a domain of actions a child can perform on his/her own. Vygotsky pointed out that it is important to distinguish between the two and emphasised that "what a child can do today in collaboration with an adult, he will be able to do on his own tomorrow" (Vygotsky, 1984, p. 264). At the same time, Vygotsky noted the importance of this concept for pedagogical work with the child and planned to explain it in further works that remained unwritten (V. K. Zaretskii, 2007, 2009).

As we continue to draw similarities between learning difficulties in psychologicalpedagogical counselling and the client's problems in psychotherapy, we state that due to the obvious lack of his/her resource (he/she would not have asked for help otherwise) a 
patient needs not just resource activation, but its widening and build-up. To accomplish this task, it is useful to consider the personal resource of the client Grawe speaks of in a differentiated way and to distinguish between things a person (adult client or child) can do on his/her own and things he/she can do only in collaboration with a helping professional (psychotherapist, psychologist, or teacher). It is this differentiation of the resource construct that enabled us to propose a notion of dual personal resource, upon which the specialist forms a therapeutic bond and decides what problems can be worked through using the client's own potential combined with the ability and readiness to accept help from others, and what problems can't be solved at the moment because this complex of conditions doesn't exist yet. Thus, we can elaborate Grawe's principal of activating resources during problem activation: the problem actualized for discussion and solving needs to lie in the zone of proximal development of the client, that is, the zone where he/she has double resource - the ability to do something on his own, and something with the therapist's help (Kholmogorova \& Zaretskii, 2010, 2011).

Grawe himself points out the condition that makes resource activation and problem activation most effective: it happens during spontaneous resource activation in a therapeutic session. The ability to detect these situations and rely on them during therapeutic work is, according to Grawe, distinguishing an effective psychotherapist from an ineffective one. Spontaneous activation of resources connected to the problem both in psychotherapy and in learning difficulties counselling is an important empiric indicator of entering the patient's (child's) zone of proximal development (Kholmogorova \& Zaretskii, 2010, 2011). At the same time, the quality of the activity (whether it is related to the problem's epicentre) and the extent of the specialist's (psychotherapist's, teacher's, counsellor's) involvement are the key factors of the intervention's effectiveness in general from the viewpoint of the development.

By the activity theory, which states that development takes place only in the process of the person's goal-directed activity, a psychotherapist's activity should broaden the zone of actual and proximal development granted that a therapist keeps track of a patient's progress and supports him/her wholesomely. More active involvement is only constructive if necessary (if difficulties arise) and in a particular form, namely, as emotional support and questions aimed at developing the reflective ability, and thus, the patient's own resource.

\section{Multivector model of mental development in the Reflection-Activity approach}

Vygotsky (1984) points out that the sphere of actions a child can perform together with an adult in the zone of proximal development should be interpreted widely as a sphere of potential cognitive and personal changes. This interpretation is a basis of the multivector model of the zone of proximal development (Fig. 1), which is interpreted as a sphere of cognitive and personal changes the child experiences in joint activity with an adult in a certain difficult situation (V. K. Zaretskii, 2007, 2009). 


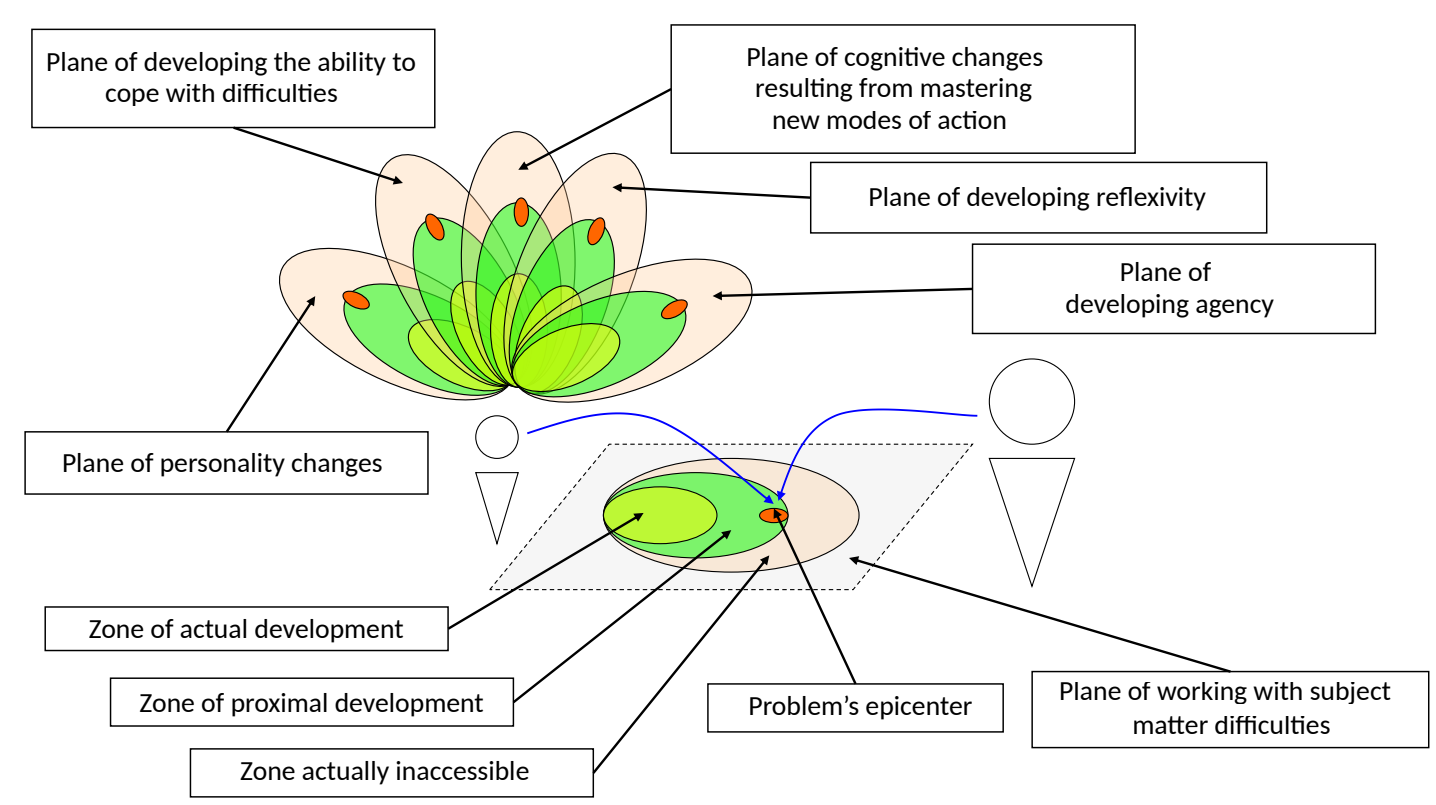

Figure 1. Zone of proximal development as an aggregate of vectors (dimensions) that can be used to make "steps" in Development in the Process of Learning (V. K. Zaretskii, 2007, 2009)

The multivector model of ZPD originated from the process of reflecting upon the practice of helping children of different backgrounds (children from comprehensive schools, with disabilities, orphans, disabled or seriously ill orphans raised in a hospital setting) in overcoming difficulties in learning. It is based on the search for "other planes" of ZPD than the plane of the school subject that was carried out by Russian researchers (Belopolskaia, 1996; Kravtsova, 2001; Obukhova \& Korepanova, 2005; Tsukerman, 2006). Describing the notion of ZPD, Vygotsky (1956) himself emphasised: "the essential characteristic of learning lies in the fact that learning creates a zone of proximal development, that is, brings to life, wakes up and sets in motion a number of inner developmental processes in a child". What did he mean by "a number of inner developmental processes"? It is known that discussing the notion of ZPD and its fundamental importance for the reinterpretation of the relationship between learning and development Vygotsky emphasised that the concept of ZPD could be extended both to cognitive functions and the development of a child in general. He also formulated an essential thesis stating that "one step in learning may signify a hundred steps in development" (Vygotsky, 1982, p. 230). From that, we can suggest that a step the child makes in learning somehow brings to life the developmental processes located in different "planes".

Every specialist knows from practical work with children that the development does not proceed smoothly, it goes in leaps. In a moment, the efforts invested in a child suddenly transform into a sudden leap in development. This leap may be connected both with a progress in acquiring subject matter knowledge (for example, a child has, at last, understood 
the meaning of mathematical operations or eliminated a long-term knowledge gap), with a breakthrough in the sphere of mental functions development (for example, a child mastered mental actions, which changed the whole system of psychic activity), or with overcoming personal barriers (for example, having successfully coped with difficulties a child starts to believe in him/herself and is ready and eager to learn).

As follows from these arguments, steps in the dimension of mastering the school subject (tagged in the scheme as "Plane of working with school subject difficulties") may bring to life, according to Vygotsky, "a number of inner developmental processes" located in different planes according to the proposed scheme:

1. in the sphere of the child's attitude towards learning as an activity (subjectivity);

2. in the sphere of meanings of learning he/she generates (reflection);

3. in different mental functions which fulfil this activity (cognitive sphere);

4. in the child's personal qualities and peculiarities, which emerge and come into play in this activity (personal sphere) (see Fig. 1).

During such interaction between the child and the adult, the former acquires the experience of overcoming learning difficulties, which may be made sense of, generalised, transformed into a method of "coping with difficulties in general" (V. K. Zaretskii, 2007). Other planes of essential change resulting from this experience can be distinguished. For example, a child may change his/her attitude towards people, first of all to adults, towards life, which becomes more meaningful and optimistic, towards the future, which becomes a place where dreams come true, and towards the past, which becomes a part of a personal story, not a sum of traumatic events to be forgotten.

As we see in these examples, pedagogical, psychological and psychotherapeutic aspects are closely intertwined. The problem's epicentre is some point where different aspects intersect; it is a central problem, which needs to be solved to launch the processes of development. Vygotsky's term that can be considered an analogue to the concept of "problem's epicentre" is the central new formation in the psyche of a school student, labelled as "the central nerve", "the axis" rotating the other processes. At the same time though he emphasised: "the most complex dynamic dependencies are formed between the process of development and the process of learning which can't be grasped by a single speculative formula given in advance" (Vygotsky, 1956). Indeed, working with a certain child, the counsellor may find out that his/her problem's epicentre is connected not to the new mental formations of the age, but to education history, family background peculiarities, past interpersonal relationships or experiencing problematic situations. Then, the therapeutic target can shift from the plane of learning difficulties or age-specific central new formation to any other plane of development where the problem is blocking development on the whole.

Vectors of agency and reflection acquire a special meaning in this model. The vector of agency signifies the person's ability to be a subject of his/her activity and its reflection 
(Y. Zaretskii \& Zaretskii, 2012; Y. V. Zaretskii, 2014). The child situated in a position of agency concerning his/her activity starts to get actively involved in the process of coping with difficulties, relying on and using the adult's help, but also taking the initiative. If a child cannot do something, but he/she can understand how this is done in cooperation with an adult, it means that the child can access this activity; it is situated in his/her ZPD. If the child is urged to act outside the borders of ZPD in the zone of actually inaccessible (that is, his/her resources aren't enough), then he/she won't be able to use help, and not only the problems won't be solved, they may become worse to the point of becoming aggravated by learned helplessness. On the contrary, in case the adult aids the child adequately, the latter develops his/her resource progressively through reflecting upon the joint activity with the adult, and becoming aware of and internalizing the tools used. Accordingly, the problems that weren't accessible at the beginning gradually become the subject of joint activity and may be solved. The close connection between different developmental vectors can be illustrated by studies showing the link between the child's position in the learning activity and his/her subjective psychological well-being (Y. V. Zaretskii, 2014), and also his/her level of empathy (Kholmogorova \& Klimenkova, 2017).

The proposed multivector model (V. K. Zaretskii, 2007, 2009, 2015, 2016) provides an opportunity to apply the concept of ZPD not only to learning difficulties in children, but to a wide array of problematic situations, which a person (a child or an adult) can't overcome on his/her own and seeks help (as it usually happens in pedagogic, counselling or psychotherapeutic work).

Multivector interpretation of ZPD contributes to the understanding of the aforementioned relation between the effectiveness of psychotherapy and therapist's sensitivity towards the client's spontaneous resource activation discovered by Grawe. "Spontaneous resource activation" signifies the possibility of development of the "agency vector", which implies the child's (client's) ability to take an active position in his/her own problems, and to define, direct and regulate the activity aimed at solving them. In the process of interaction between a child and an adult (a client and a psychotherapist), each of them makes a possible contribution in joint activity. The growth of the input from the child (or client) signifies the development of his/her subjectivity. Thus, the child's position of agency becomes the most significant condition of cooperation and, accordingly, the prerequisite of its effectiveness. Consecutive support of a child's position of agency in learning difficulties counselling may be defined as another basic value, which operationalizes Vygotsky's thesis about cooperation as a special development-stimulating type of interaction between a child and an adult. It should be shared by every specialist who aims at enhancing development.

In this context, Grawe's results can be interpreted as an important principle of counselling children or adults. Counselling is most effective when the specialist supports the child's (client's) position of agency. We emphasise this once more: one of the most important qualities in a counsellor is his/her sensitivity to the child's (client's) sense of agency, which needs to be relied on when working towards solving an actual problem (overcoming a certain difficulty) or building-up the client's resource (enhancing development). This statement is vividly illustrated by Vygotsky's thesis which was considered an enigma for a 
long time: "one step in learning may signify a hundred steps in development" (V. K. Zaretskii, 2015, 2016). In case a specialist works with a child in the manner discussed above his/her mastery of certain skills (modes of action) is accompanied by his/her growing activity, self-confidence, awareness of his/her resources and the spheres where assistance is needed, and the ability to seek and use help. A child becomes less and less dependent on the helping adult, more able to solve problems on his/her own and to distinguish between things he/she can do with or without help, and more knowledgeable in the kind of aid he/she needs.

\section{Reflection and its applications in learning difficulties counselling}

As we noted above, being an agent implies being an agent of activity and reflecting upon it. A Reflective Form is an RAA technique that realises this notion (V. K. Zaretskii \& Gilyazov, 2016). It is a table with two columns where a child in cooperation with an adult captures dual resource, differentiates between his/her own abilities and the assistance provided by the counsellor. In the last row, the counsellor formulates the problem that can be solved by the child's resource (the hypothesis about the problem's epicentre), and plans the next step in counselling.

Based on the notion that the process of reflecting upon one's activity is significant for the child's development we suggest that the specialists aiding children with learning difficulties (teachers, psychologists) capture the process and the results of the joint activity in a table containing the following questions:

1. What could the child do by him/herself? (Zone of actual development);

2. What couldn't the child do by him/herself? (What mistakes he/she made, what could he/she do with the adult's assistance?);

3. What kind of aid did the child need? (What exactly did the adult?);

4. What did this aid give him/her? (Did the adult help the child overcome difficulties, how exactly?);

5. What will be the next step? (What is sensible to do next to achieve the next stage of learning and development? Ideally, problem's epicentre should be described.)

Naturally, elementary school pupils, as well as some adolescents, cannot fill in this table on their own. They need adult's assistance. As the child and the adult make sense of the executed activity together, the latter comprehends what the child can make sense of unaided, and what is yet outside his/her understanding. That is, the counsellor's task here is to discover the zones of actual development, proximal development and the actually inaccessible in the child's reflection. 
We would like to give a few examples, which illustrate the relationship between cognitive, personal and interpersonal aspects (vectors) of development in the process of overcoming general learning difficulties. These examples indicate that reflection aimed at differentiating the child's resource and the shared resource in cooperation with the adult plays a major role in overcoming these problems and initiating development (Tables 1, 2, and 3). All the names in the examples are changed to provide anonymity.

Table 1 describes the process of joint reflection taking place at the end of the maths lesson with a second-grade pupil who has fallen behind the class in this subject. The form shows the student's attempts to reflect and the way the counsellor captures the process. As this lesson is the first the boy has with the tutor, it is clear that he cannot make sense of his actions yet even with the adult's help.

Table 1

Reflective form for capturing dual resource and defining the problem's epicentre (Vanya's case, age 8,2 nd grade).

What could you do by yourself?

What couldn't you do by yourself?

What kind of help did you need?

What did this help give you?

Commentary (hypotheses about ZPD, resource and the problem's epicentre)
Written down from Vanya's words:

He wrote, read and drew arrows.

(The tasks required him to connect actions and variants of answers)

He cannot answer.

(Vanya's reflection shows that the meaning of mathematical operations is concealed from him. Naturally, Vanya himself cannot formulate it)

He cannot answer.

(The help was aimed at clarifying the meaning of the tasks)

Vanya notes that he managed to complete the task using the counsellor's assistance.

(It helped him to understand the tasks, but didn't make sense of mathematical operations)

In his reflexive activity, Vanya notes only the outer operational side of the actions performed ("I wrote, read...").

Mathematical operations are still a mystery to Vanya, these manipulations with numbers carried out according to certain rules do not make sense to him. The meaning of these rules is still, probably, out of the boundaries of ZPD. How should we approach them? - Probably, by involving Vanya in measuring activity, where operations and numbers can acquire specific meaning.

Table 2 describes the counsellor's reflection following the lesson in Russian with a firstgrade pupil, whose parents sought help due to frequent gross mistakes he made in this subject. The table contains the counsellor's reflections during the lesson, particularly on 
Table 2

Reflective form for capturing dual resource and defining the problem's epicentre (Vanya's case, age 8,2 nd grade).

What could you do by your- Can't express his thoughts, agrees with the counsellor's opinion self?

during joint reflection (as follows):

Wrote simple words in clumsy irregular script, making "stupid" mistakes (Misha's expression); omitted, misplaced and inserted wrong letters (words from the task did not imply using grammatical rules). He was not dictating to himself, that is, spelling out what he was writing either orally or to himself.

He understood the counsellor's explanation why spelling out words out loud is important.

What couldn't you do by This question was not raised because Misha is overly sensitive yourself? to making mistakes and facing difficulties, he perceives them as proof of his failure. He also refused to write complex words, spelling them out loud. When the counsellor asked him why, whether he was not interested or didn't feel confident, he answered: "I am not confident in myself!"

What kind of help did you need?

This question was not raised either. To eliminate "stupid" mistakes, Misha was advised to spell the words out loud (first aid). To address the statement "I am not confident in myself", the counsellor said: "You are not confident that you can do it on your own, but I am helping you after all. Together we can do it! You do believe that I can help you, right?" (second aid).

What did this help give you? From Misha's words: "Spelling the words out loud I made fewer mistakes".

The first aid helped Misha to understand the meaning behind spelling words out loud to eliminate mistakes of a certain type, but it was not effective enough, and Misha did not start to spell the words correctly.

The second aid (which wasn't discussed with Misha) enabled him to get to work and try to write and spell words out loud at the same time.

Commentary (hypotheses about $\mathrm{ZPD}$, resource and the problem's epicentre)

Hypothetically the problem's epicentre, in this case, is an absolute lack of confidence and extreme sensitivity towards any mistake coupled with a belief mistakes are unavoidable. Misha avoids learning activity as a source of painful experience. It is imperative for him to reach real success, based on the new skills, to make sure that overcoming mistakes is possible, and he can do it. Things that helped him cope with mistakes need to be captured during reflection.

the problem, which was implicitly targeted during the session, without being discussed with the boy (in the "Commentary" section, last row). 
Table 3

Reflective form for capturing dual resource and defining the problem's epicentre (Katya's case, age 9, 3rd grade).

$\begin{array}{ll}\text { What could you do by your- } & \text { (Written by the counsellor, the girl practically refused to reflect } \\ \text { self? } & \text { upon her performance). } \\ & \text { She can copy words, although not in the most efficient way (she } \\ & \text { copies words in parts and single letters, which poses a threat } \\ & \text { of mistakes connected to attention span). The result is reached } \\ & \text { mostly due to her high motivation and energy as opposed to } \\ & \text { perfect methods and mastery. }\end{array}$

What couldn't you do by She reads a syllable a time, doesn't understand texts as she reads yourself? them and needs explanations.

She knows word parts, but can't mark them out.

She does not understand the definition of word parts.

She faces difficulties making generalisations even based on her reflection upon her actions.

What kind of help did you need?

Assisted in working with text, in marking out the meaningful parts of a definition.

Provided assistance in using a definition as an instrument to differentiate between different word parts.

Given training materials (study cards, examples, inscriptions) to make the process more visual.

Assisted in checking what actions were performed.

Aided in making generalisations.

What did this help give you? The task was completed successfully and more or less understood. She was interested in studying.

In the end, she said she liked everything.

Commentary (hypotheses about ZPD, resource and the problem's epicentre)

During reflection, Katya said she had not done anything by herself. At the same time, she aimed at completing the task excellently. This problem can be defined as follows: her self-esteem is too low, but her aspiration level is too high. Her focus on the goal as opposed to appreciating the value of learning is also concerning, although she starts to enjoy the process and studies with interest. She understands the meaning of the tasks poorly; rushes to act before she has understood the task; faces difficulties in making sense of what she does and how she acts on her own. We see this as a key to eliminating the gap between self-esteem and aspiration level and helping Katya to master such mental abilities as understanding and generalisation. Apparently, reflecting upon her activity is a principal target and focus of the difficulties we should be working with. 
Table 3 describes the case of a girl, third-grade pupil, who makes many mistakes and has fallen behind the class in Russian. She knows enough but faces difficulties applying her knowledge. Reflection shows that she lacks adequate comprehension of her own and joint activity, which the counsellor proposes as her chief difficulty and the hypothetical problem's epicentre.

The practice of helping children overcome learning difficulties convincingly shows that reflection plays the most important role both in coping with the problems and in the development of other vectors affected by the activity.

In accordance with this notion, we consider studying functions of reflection in the process of coping with problems (narrowly: overcoming learning difficulties) the next step in researching reflection. In 1970s-1980s experiment as a method of studying reflection attracted the attention of the psychology of thinking. We were the first to compare the reflective regulation of cognition in solving creative problems in the normative and clinical samples. There we distinguished between the control (becoming aware of and analysing the established mode of actions) and constructive (rebuilding inadequate foundations and elaborating new ways of action) functions of reflection (V. K. Zaretskii \& Kholmogorova, 1983). In 2001, in a special issue of Moscow Psychotherapeutic Journal on the topic "CognitiveBehavioural Therapy" we compared the notions of Russian psychology of thinking and the principles of cognitive therapy and showed that the latter aims at developing reflective ability (Kholmogorova, 2001). Comparative analysis of classical cognitive therapy developed by A. Beck (Beck, Rush, Shaw, \& Emery, 2003) and new techniques which emerged in the so-called "third wave" of this approach yielded two more functions of reflection: differentiative (aimed at distinguishing and separating different contents and actions) and integrative (aimed at making connections between different contents, actions and their consequences) (Kholmogorova, 2016).

Relying on the difference between the mentioned functions of reflection and the scheme of the reflective act based on Johann Fichte's ideas, developed by Alekseev (2002) and supplemented by V. K. Zaretskii $(1984,2013)$ we carried out a comparative analysis of the counsellor's work with the subject-related aspect of learning difficulties and the therapist's work with the personal aspect. The results yielded by the analysis are presented in Table 4. The first column shows the scheme of the reflective act, which consists of six successive actions and has been supplemented by the seventh action aimed at differentiating between the two aspects of dual resource while aiding a person with learning difficulties. The second column reveals the implementation of this scheme during work with action schemas using RAA techniques (cognitive vector), the third deals with cognitive-behavioural therapy (personal vector) focusing on the personal vector. Notably, differentiating between the client's resource and joint resource in the last step is principally important not only for the cognitive and personal vectors, but also for the vector of interpersonal relations - that is, for the development of the ability to cooperate with the adult constructively; and for the vector of subjectivity - that is, the ability to plan one's activity and seek help independently. 
Table 4

Comparison of counsellor's work in RAA paradigm with an action schema and a psychotherapist's work in CBT paradigm with emotional state and behaviour of a child with learning difficulties.

\begin{tabular}{lll}
\hline $\begin{array}{l}\text { Modified scheme } \\
\text { of reflective act by }\end{array}$ & $\begin{array}{l}\text { RAA counsellor's work aimed at } \\
\text { enhancing a child's mental devel- }\end{array}$ & $\begin{array}{l}\text { CBT psychotherapist's work } \\
\text { aimed at enhancing a child's men- }\end{array}$ \\
$\begin{array}{l}\text { N. Alekseev and V. } \\
\text { opment in the process of rebuild- }\end{array}$ & $\begin{array}{l}\text { tal development in the process } \\
\text { ing his/her ways of studying a cer- } \\
\text { tain school subject }\end{array}$ & $\begin{array}{l}\text { managing his/her emotions and } \\
\text { behaviours }\end{array}$ \\
\hline
\end{tabular}

Control function of reflection

$\begin{array}{ll}\text { 1) Stop of ideation "What are you doing right now?" } & \text { "What thoughts / images flashed in } \\ -\quad \text { pausing one's } & \text { your mind when you experienced } \\ \text { thoughts (actions) } & \text { this?" }\end{array}$

\begin{tabular}{lll}
\hline Control function of reflection & & \\
\hline 2) Fixation of Describing one's action & $\begin{array}{l}\text { Formulating } \\
\text { thoughts }\end{array}$ & \\
ideation - cap- & & \\
turing thoughts & & \\
(actions) & &
\end{tabular}

Control function of reflection

$\begin{array}{llll}\text { 3) Objectivation of } & \text { Analysing one's action (action as an } & \begin{array}{l}\text { Assessing automatic thoughts } \\ \text { ideation - thoughts } \\ \text { (actions) objectiva- }\end{array} & \text { object), exposing the reasons behind } \\ \text { (thought as an object), revealing } \\ \text { tion }\end{array}$

Differentiative function of reflection

4) Estrangement of Describing one's erroneous mode of ideation - thoughts action in a certain task (thus, freeing (actions) alienation oneself from the unconscious mode of action)
Formulating the alternative view (freeing oneself from the usual view of the situation and emotional reactions and behaviours connected with it)

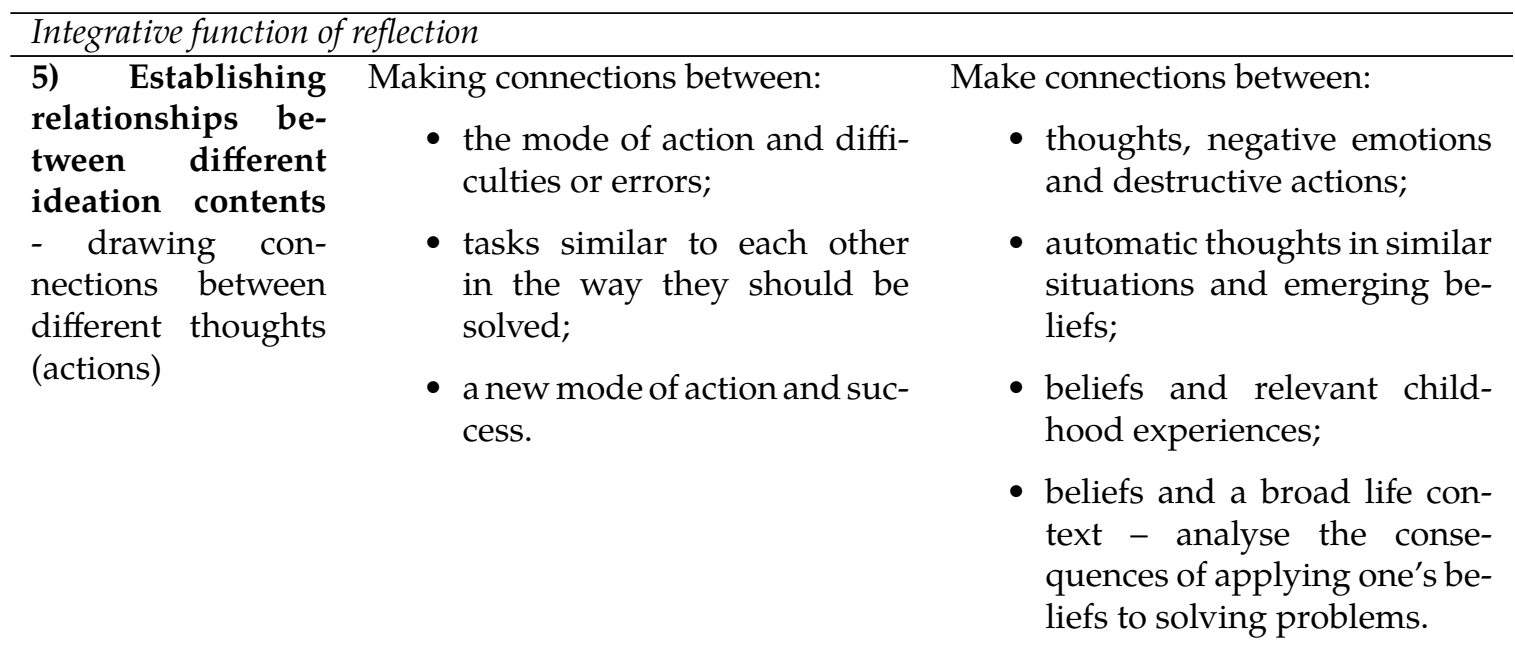




\begin{tabular}{|c|c|c|}
\hline \multicolumn{3}{|c|}{ Constructive function of reflection } \\
\hline $\begin{array}{l}\text { 6) Change of } \\
\text { ideation founda- } \\
\text { tions - changing } \\
\text { the basis of cogni- } \\
\text { tion }\end{array}$ & $\begin{array}{l}\text { Deliberate renunciation of the old } \\
\text { manner of action and moving on to } \\
\text { the new one }\end{array}$ & $\begin{array}{l}\text { Deliberate, purposeful rebuilding } \\
\text { of dysfunctional beliefs and related } \\
\text { non-adaptive emotional reactions } \\
\text { and behaviours }\end{array}$ \\
\hline \multicolumn{3}{|c|}{ Constructive function of reflection } \\
\hline $\begin{array}{l}\text { 7) New step-draw- } \\
\text { ing connections } \\
\text { between different } \\
\text { aspects of coping } \\
\text { with difficulties } \\
\text { (double resource } \\
\text { disclosure) }\end{array}$ & $\begin{array}{l}\text { When overcoming learning difficul- } \\
\text { ties a connection should be drawn } \\
\text { between personal resource ("what } \\
\text { I did on my own / what I learned } \\
\text { to do") and joint resource ("what I } \\
\text { needed assistance in / what I have } \\
\text { yet to learn or change") }\end{array}$ & $\begin{array}{l}\text { When overcoming emotional diffi- } \\
\text { culties in learning activity a connec- } \\
\text { tion should be drawn between per- } \\
\text { sonal resource ("what I did on my } \\
\text { own / what I learned to do") and } \\
\text { joint resource ("what I needed as- } \\
\text { sistance in / what I have yet to learn } \\
\text { or change") }\end{array}$ \\
\hline
\end{tabular}

Thus, we can draw the following conclusions:

1. A child's learning difficulties are determined by different mental mechanisms blocking development in general. Cultural-historical psychology contains the model of mental development that can be used in various forms of aiding children with learning difficulties, which are connected by the notion of development enhancement. At the same time, the core value of this type of assistance is a cooperation between a child and an adult in the zone of proximal development.

2. Supplementing the notion of ZPD with dual resource enables the counsellors to operationalize the diagnostics of ZPD, use new techniques and deliberately assist development in different directions, above all, the child's position of agency in the process of overcoming learning difficulties.

3. RAA further develops the theses of cultural-historical psychology, specifically, in the multivector model of mental development, which includes the following vectors of development: mastery of the subject, cognitive functions, personal characteristics, reflective ability, coping with difficulties, emotional regulation, interpersonal relations, and others. The model can be used to distinguish the key problems and to coordinate the efforts made by different specialists aiding the child with learning difficulties.

4. Despite working in different theoretical frameworks with various aspects of learning difficulties, an RAA counsellor working with action schemas and a cognitivebehavioural therapist focused on the child's emotional and behavioural problems are united by the goal of building-up reflection, including its control, constructive, differentiative and integrative functions. This goal also contributes to the child's general development in different spheres.

To summarise, we will once more return to the notion of major importance to effective counselling work with a child experiencing learning difficulties. It is a concept of the prob- 
lem's epicentre - that is, a fundamental problem localised on one of the developmental vectors and blocking the attempts to overcome difficulties (V. K. Zaretskii, 2016). Discovering the problem focus presents a genuinely creative task for the specialist, but it is this task that can greatly spur development and by taking a single step in learning make a hundred in development.

In the previous works (Kholmogorova, 2016; Kholmogorova \& Zaretskii, 2010), we have already quoted Henri Ellenberger, the renowned historian of psychoanalysis, stating that the criterion indicating the psychotherapist's professionalism is an ability to foresee (guess) the moment when a certain intervention is most effective. At that, he refers to the notion of "kairos", proposed by Hippocrates. Kairos signifies a turning point in the progress of illness when the person's state can suddenly change either for the better or the worse. Hippocrates regarded the art of medicine in the ability to catch these moments and use them to help the patient fight the illness. According to Ellenberger (2001), a good therapist always knows that a special moment comes when a certain patient is inwardly ready to accept a certain intervention, which is only effective in this very moment, whereas before it was premature, and after it will be futile.

An example of such intervention is again provided by Arnhild Lauveng (widely popular in psychotherapeutic literature) who suffered from a severe chronic form of schizophrenia which started when she was an adolescent (Lauveng, 2009). In the book Tomorrow I Was Always A Lion she describes the turning point of her illness - a conversation with a social worker about a possible occupation. During the conversation, she disclosed her dream of getting a medical education and helping mentally ill people. Her chronic illness and frequent hospital admissions might have made the social worker consider this wish dangerously out of touch with reality, discard it and suggest she set a more realistic goal. Instead the social worker, who probably intuitively relied on the vector of agency, planned the progress towards this dream together with Lauveng. They started out by defining her current possibilities and the requirements she needed to reach her goal, what Arnhild could do by herself and where she needed help from the social worker. That is, this specialist was intuitively relying on Arnhild's zone of proximal development and at the same time differentiating between her resource and the area of applying joint efforts - thus, she used the dual resource. As a result, a so-called miracle happened - Arnhild got well and wrote a world-famous book about her illness, which has been translated into many languages. Sceptics may say it is all about the change in the progress of the illness. However, we envision Vygotsky replying to them: "One step in learning can lead to a hundred steps in development. This is indeed the most positive aspect of the new theory" (Vygotsky, 1982, p. 230).

\section{References}

Alekseev, N. G. (2002). Proektirovanie uslovii razvitiya refleksivnogo myshleniya: diss. . dokt. psikhol. $n$. $v$ vide nauchnogo doklada [Designing the conditions of developing reflexive thinking: Ph.D. diss. in the form of a scientific report]. Moscow: MPGU Press. 
Beck, A. T., Rush, A. J., Shaw, B. F., \& Emery, G. (2003). Cognitive therapy of depression. New York: Guilford Press.

Belopolskaia, N. L. (1996). Assessment of cognitive and emotional components of the zone of proximal development in mentally retarded children. Journal of Russian $\mathcal{E}$ East European Psychology, 34(1), 46-56.

Blonskii, P. (1979). Zadachi i metody novoi narodnoi shkoly [The aims and methods of the new public schools]. In Izbrannye pedagogicheskie i psikhologicheskie sochineniya.t. 1. [selected pedagogical and psychological works: Volume 1] (p. 304). Moscow: Pedagogika.

Caspar, F. (2010). Modeling the therapeutic relationship and resource orientation: Introduction. abstract. In FMPP annual congress of psychiatry and psychotherap//20 th IFP world congress of psychotherapy (p. 47). Luzerne, Switzerland: KKL.

Dzhurinskii, A. N. (2008). Istoriya obrazovaniya i pedagogicheskoy mysli [The history of education and pedagogical thought]. Moscow: Vlados Publisher.

Ellenberger, H. (2001). Klinicheskoe vvedenie v psikhiatricheskuyu fenomenologiyu i ekzistentsial'nyi analiz [Clinical introduction to psychiatric phenomenology and existential analysis. In Ekzistentsial'naya psikhologiya. Ekzistentsiya [Existential psychology. Existence] (pp. 201-236). Moscow: EKSMO-Press.

Grawe, K. (2006). Agents of change in the processes of psychotherapy. Part I. IFP newsletter, 7-17.

Kholmogorova, A. B. (2001). Kognitivnaya psikhoterapiya i otechestvennaya psikhologiya myshleniya [Cognitive psychotherapy in russia psychology]. Moskovskii psikhoterapevticheskii zhurnal [Moscow Psychotherapeutic Journal](4), 165-181.

Kholmogorova, A. B. (2016). Kognitivno-bikhevioral'naya terapiya «na grebne tret'ei volny»: revolyutsionnyi povorot ili novye aktsenty? [Cognitive-behavioral therapy "on the crest of the third wave»: a revolutionary new turn or new accents?]. Sovremennaya terapiya psikhicheskikh rasstroistv [Modern therapy of mental disorders](2), 16-21.

Kholmogorova, A. B., \& Klimenkova, E. N. (2017). Empathic ability in the context of the subjectivity problem. Counseling Psychology and Psychotherapy, 25(2), 75-93.

Kholmogorova, A. B., \& Zaretskii, V. K. (2010). Mozhet li byt' polezna rossiiskaya psikhologiya $\mathrm{v}$ reshenii problem sovremennoi psikhoterapii: razmyshleniya posle $x x$ kongressa internatsional'noi federatsii psikhoterapii (IFP) [Can russian psychology be helpful for solving the problems of modern psychotherapy: reflection after the $10^{\text {th }}$ congress of the international federation of psychotherapy (IFP)]. Meditsinskaya psikhologiya $v$ Rossii: elektron. nauch. zhurn [Medical psychology in Russia: online journal](4).

Kholmogorova, A. B., \& Zaretskii, V. K. (2011). C mozhet li kul'turno-istoricheskaya kontseptsiya L. S. Vygotskogo pomoch' nam luchshe ponyat', chto my delaem kak psikhoterapevty [Can Vygotsky's cultural-historical concept help us to better understand what we do as therapists?]. Kul'turno-istoricheskaya psikhologiya [CulturalHistorical Psychology](1), 108-118.

Kravtsova, E. E. (2001). Kul'turno-istoricheskie osnovy zony blizhaishego razvitiya [Cultural-historical foundations of the zone of proximal development]. Psihologicheskii zhurnal, 22(4), 42-50.

Lauveng, A. (2009). Zavtra ya vsegda byvala l'vom [Tomorrow I was always a lion]. Samara: «Bakhrakh-M» Publisher. 
Nikolaevskaya, I. (2017). Multidimensional model of the ZPD as tool of analysis of the child's cognitive-personal dynamics of development while overcoming learning difficulties. Revue internationale du CRIRES: Innover dans la tradition de Vygotsky, 4(1), 154-160.

Obukhova, L. F., \& Korepanova, I. A. (2005). Prostranstvenno-vremennaya skhema zony blizhaishego razvitiya [spatial-time scheme of the zone of proximal development]. Voprosy psikho logii [Questions of psychology](5), 13-26.

Tsukerman, G. (2006). Vzaimodeistvie rebenka i vzroslogo, tvoryashchee zonu blizhaishego razvitiya [Cooperation between a child and an adult creating the zone of proximal development]. Kul'turno-istoricheskaya psikhologiya [Cultural-Historical Psychology], 4, 61-73.

Vygotsky, L. S. (1956). Problema obucheniya i umstvennogo razvitiya v shkol'nom vozraste [Issue of learning and mental development in school-aged children]. In Izbrannye psikhologicheskie issledovaniya [selected psychological works] (pp. 438-452). Moscow: APN RSFSR Publisher.

Vygotsky, L. S. (1982). Collected works in 6 volumes. Vol. 2. Moscow: Pedagogika.

Vygotsky, L. S. (1984). Collected works in 6 volumes. Vol. 4. Moscow: Pedagogika.

Zaretskii, V. K. (1984). Dinamika urovnevoi organizatsii myshleniya pri reshenii tvorcheskikh zadach: Avtoref. diss.... kand. psikhol. nauk [the dynamics of organising thinking in creative problem solving: Ph.d. (psychology) thesis]. Moscow.

Zaretskii, V. K. (2007). Zona blizhaishego razvitiya: o chem ne uspel napisat' vygotskii [Zone of proximal development: what vygotsky had not time to write about]. Kul'turno-istoricheskaya psikhologiya [Cultural-Historical Psychology](3), 96-104.

Zaretskii, V. K. (2009). Zone of proximal development: What Vygotsky didn't have time to write. Journal of Russian and East European Psychology, 47(6), 70-93.

Zaretskii, V. K. (2013). Traektorii razvitiya predstavlenii o refleksii i ikh ispol'zovanie v praktike organizatsii resheniya problem [trajectories of development of the notions of reflection and its applications in the practice of organised aid in solving problems]. Psikhologiya v vuze [Psychology in Higher School](4), 55-97.

Zaretskii, V. K. (2015). Teorema L. S. Vygotskogo "Odin shag v obuchenii - sto shagov v razvitii»: v poiskakh dokazatel'stva [L. S. Vygotsky's Principle “one step in learning - a hundred steps in development": In search of evidence]. Kul'turno-istoricheskaya psikhologiya [Cultural-Historical Psychology], 11(3), 44-63. doi: $10.17759 /$ chp. 2015110305

Zaretskii, V. K. (2016). Odin shag v obuchenii - sto shagov v razvitii: Ot idei k praktike [Vygotsky's Principle "One step in learning - One hundred steps in development": From idea to practice]. Kul'turno-istoricheskaya psikhologiya [Cultural-Historical Psychology], 12(3), 149-188.

Zaretskii, V. K., \& Gilyazov, A. (2016). Shakhmaty dlya obshchego razvitiya. rabochaya tetrad' dlya zanyatii shakhmatami [Chess for general development. A workbook for chess studies]. Moscow: «Raikhl'» Publisher.

Zaretskii, V. K., \& Kholmogorova, A. B. (1983). Smyslovaya regulyatsiya resheniya tvorcheskikh zadach [Meaning regulation of creative problem solving]. In Issledovaniya problem psikhologii tvorchestva [Studying the issues of psychology of creativity] (pp. 62100). Moscow: Nauka. 
Pedagogical, Psychological and Psychotherapeutic Help...

Zaretskii, Y., \& Zaretskii, V. K. (2012). Sub'ektnaya pozitsiya rebenka v preodolenii uchebnykh trudnostei [subject position of the child in overcoming learning difficulties (case study)]. Konsul'tativnaya psikhologiya i psikhoterapiya [Counseling Psychology and Psychotherapy](2), 110-133.

Zaretskii, Y. V. (2014). Sub'ektnaya pozitsiya shkol'nikov po otnosheniyu k uchebnoi deyatel'nosti $v$ raznykh vozrastnykh periodakh [Schoolchildren's position of agency towards the learning activity in different ages. Moscow: Ph.D. (Psychology) Thesis. 